ture, the two members who have acted in cooperation with the committee to be formally added to that body; and that the president of the Botanical Society appoint additional members, one with a special knowledge of the Bryophyta or Pteridophyta, one with a special knowledge of the Algæ, and two with a special knowledge of fungi.

2. This committee shall investigate doubtful or questioned cases, either upon its own initiative or in response to requests, and shall recommend decisions. It may prepare a code of Botanical Nomenclature and may, at regular meetings of the society, recommend changes or additions to the code. It is suggested that the committee undertake, as soon as practicable, the typifying of the Linnæan genera, as this must be the basis of all future work,

\section{SPECIAL ARTICLES \\ TEMPERATURE AND VERTEBRE IN FISHES; A SUGGESTED TEST}

IN 1862, Dr. Günther ${ }^{1}$ noted that in the family of Labridæ (Wrasse fishes) the tropical species had $24(10+14)$ vertebræ while those of temperate seas had a larger number, the increase being mainly in the caudal region.

In 1863, Dr. Gill showed that this generalization could be extended to other families, and that it was to "be considered in connection with the predominance in northern waters" of soft-rayed fishes" in which the increase in the number of vertebræ is a normal feature." This generalization thus included the herring, trout, salmon, smelt, cod, flounder and their relatives, and might have been extended to the sculpins, greenlings and other spiny-rayed fishes-northern types as well.

In 1864, Dr. Gill noted that the northern genus, Sebastes, with $12+19=31$ vertebræ showed a similar relation to its tropical relative Scorpcena, with $10+14=24$.

In various papers, the present writer has extended this generalization to numerous other families, raising it to the dignity of a "law." In general, among, spiny-rayed fishes, the tropical forms have the vertebræ $10+14$, the northern

\footnotetext{
1 "Catalogue of the Fishes of the British Museum," Vol. IV.
}

forms, fresh-water forms, pelagic species and deep-sea representatives a larger number. In the groups of soft-rayed fishes, the vertebræ in the tropics usually range higher than 24 (35 to 43) among flounders while the subarctic species all run higher (among flounders 49 to 65 ). The sub-Arctic blennies have the vertebræ 75 to 100 , their tropical relatives 28 to 49 . Some such relation exists in every group-eel-shaped fishes excepted. These have no northern representatives and in them the whole body is peculiarly modified in accordance with their mode of life.

The facts being fairly established we look next to its explanation. Dr. Gill states (1889) that "it is simply the expression of a fact which has no cause for its being now known." $\mathrm{He}$ further doubts whether it can ever be ascertained.

In my own first paper on the subject ${ }^{2}$ I suggested that the larger numbers might be primitive, and that the smaller numbers (accompanied by corresponding increase in complexity of the individual vertebræ) were the result of specialization or "ichthyization," a process which in the favoring temperature, amid intense competition of the tropics and especially about coral-reefs, brought about the more perfect or fish-like fish.

I am now, however, inclined to accept Dr. Boulenger's suggestion that the increased numbers and the lack of specialization of parts is the result of a form of degeneration, and that the lower number is a primitive trait possessed by the ancestors of most of the higher bonyfishes.

One way of testing this has occurred to me. The genus Sebastodes and its near allies ("rockcod") form a large part of the temperate fishfauna of California and Japan. These stand intermediate in characters as well as in geography between the subarctic rose-fishes (Sebastes, Sebastolobus, etc.) and the tropical scorpion-fishes (Scorpcena, Helicolenus, etc.) with their derivatives and allies.

In Sebastes, the vertebræ are $12+19=31$; in Sebastodes, $12+15=27$, and in Scorpcena, $10+14=24$. The species of Sebastes and

2 Proc. U. S. Nat. Mus., XIV., 1891. 
Sebastodes are viviparous, the young being developed internally and in multitudes, to be extruded when about two or three millimeters in length. The development of the young should indicate the phylogeny of the group. If the total number of vertebræ in Sebastodes is 24, we may infer with strong plausibility that Scorpcena, with its 24 vertebræ was the ancestral type. If the number is 31 we would grant this place to Sebastes. In either case, Sebastodes is intermediate.

Through the interest of Professor Edwin C. Starks, I have secured a number of young of a species of Sebastodes from Long Beach, California. These are very recently hatched, one to two millimeters in length. Vertebræ do not appear, but the muscular impressions which will correspond to them are 27 in number.

This agrees with the number of vertebræ in the adult of all the Sebastodes recorded. This test, therefore, fails to decide the question of origin, though it may be held to show that the separation of Sebastodes from Sebastes or from Scorpcena is really very old, and in spite of the strong resemblances of the forms concerned.

I may further note that all allies of Scorpona with 24 vertebræ have 12 spines in the dorsal fin, Sebastodes, and its relatives with 27 vertebræ have 13, and Sebastes, with 30 or 31 vertebræ, has 15 or 16 dorsal spines, the numbers of fin rays corresponding in a degree to the number of vertebral segments.

\section{David Starr JoRdan}

Since the above was in type, I have obtained from the diatomaceous shales of the Puente formation (Miocene) of Orange, California (E. E. Hadley coll.), a fossil fish apparently of the Sebastodes group. This specimen has the vertebræ about 32 in number, $10+20$ being preserved. The head of the specimen is lost, but the fish must belong to the Sebastince, as no other forms unite the characters of stiff dorsal spines, anal rays III, 10, with small scales and the vertebræ more than 24. In other respects, this new genus (soon to be described and figured), seems nearest Sebastosomus Gill (S. mystinus). The discovery of this form is again not decisive, though it indicates the possibly primitive character of the Sebastina fishes having the larger numbers of vertebræ.

\section{David StarR JordaN}

\section{THE AMERICAN ASSOCIATION OF PETROLEUM GEOLOGISTS}

THe fourth annual meeting of the American Association of Petroleum Geologists was held at the Adolphus Hotel, Dallas, Texas, on the 13 to the 15 of March. More than two hundred petroleum geologists and a great number of visitors were present from all portions of the United States, the association being especially honored by the presence of David White, chief geologist of the U. S. Geological Survey; I. C. White, state geologist of West Virginia; Ralph Arnold, valuation expert of the Internal Revenue Department of the U. S. Treasury, and Professor Chas. Schuchert, of Yale University.

The opening meeting of the association was called to order on Thursday morning by the president, Alexander Deussen. Gilbert H. Irish, of the Dallas Chamber of Commerce, delivered an address welcoming the geologists to Dallas. Short talks were made by Dr. David White, Dr. I. C. White; Dr. J. A. Udden, state geologist of Texas; W. F. Cummins; J. A. Taff, of San Franciseo, and Leo Hager, of Houston.

The first technical session was held Thursday afternoon, attention being devoted to the geology of the oil producing districts of north central Texas. John A. Udden, chief geologist of the Sinclair Oil Company, read a paper dealing with the subsurface geology of the oil-producing districts of 'north central Texas, and accompanied his paper by a set of well samples and slides of the formations penetrated in some of the wells of north central Texas. Chas. R. Eckes, chief geologist of the Texas Company, gave a description of cuttings from the Duffer well of the Texas Company at Ranger, and displayed a set of samples from this well. F. B. Plummer, of the Roxana Petroleum Company, gave a deseription of the cuttings from the Goode well of the Roxana Company, in Young County, and the Dye well in Palo Pinto County. Wallace E. Pratt, chief geologist of the Humble Oil a Refining Company, read a paper entitled "Notes on structure of surface rocks as related to subsurface structure and petroleum accumulation in north Texas." Dr. David White read a paper by G. H. Girty, on the "Bend formation and its 